\title{
Key Performance Indicators for Sustainable Freight Transport and Scenario-based Impediments in Pakistan Freight Industry
}

\author{
Nazam Ali ${ }^{1}$, Muhammad Ashraf Javid ${ }^{2}$, Syed Arif Hussain ${ }^{3}$, and Muhammad Abdullah ${ }^{4}$ \\ ${ }^{1}$ Division of Environmental Design, Kanazawa University, Japan \\ ${ }^{2}$ Department of Civil and Environmental Engineering, University of Nizwa, Sultanate of Oman \\ ${ }^{3}$ Department of City and Regional Planning, University of Engineering and Technology, Pakistan \\ ${ }^{4}$ Department of Civil Engineering, School of Engineering, University of Management and \\ Technology, Pakistan \\ e-mail:nazamali755@gmail.com
}

\begin{abstract}
Freight transport enables economic growth, market connectivity, and access to the global supply chain systems which contribute to the societal progress and inclusive development of a country. However, it may undermine the sustainable operations by incurring external costs, inefficiency, and economic losses due to non-reliability, poor services, and information systems. In this research study, the Key Performance Indicators (KPIs) for Sustainable Freight Transport Systems (SFTS) are discussed based on available literature review and standards of sustainability measurement in freight transport. Then, based on KPIs some of the scenariobased impediments are highlighted which hinder the performance of the freight transport in Pakistan for achieving sustainable development goals. The core impediments included are Strategic Determinants (SD), Information Systems (IS), Infrastructure Management Systems (IMS) and City Logistics (CL). The negative direct impacts of the key identified factors are also highlighted and linked with each scenario-based impediment. This research study would provide an opportunity for the stakeholders to get tangible idea for policy making and upgradation of the freight transport industry in the country. The highlighted implications will also be validated via expert surveys and Delphi-analysis in the future study.
\end{abstract}

Keywords-Freight Transport, Sustainable Transport, Key Performance Indicators, Scenario-based Impediments, Pakistan Freight Industry.

\section{INTRODUCTION}

F REIGHT transport in many of the emerging countries faces various well-known and serious issues which hinder the sustainability perspectives of its operations [1]. In recent times, freight transport is directly linked with the economic growth, market connectivity, and access to the global supply chain systems, which are imperative piers of economic and societal developments in modern communities [2]. However, the recent massive influx of increased transit operations in the freight industry have yielded many of the negative externalities such as excessive operating costs, inefficient operations, economic losses and societal concerns which are result of poor planning, management, and services and insufficient information systems in the freight industry. These negative externalities have demonstrated a lack of sustainable approach in the freight industry especially in developing nations [3].
Table 1.

Main connecting hubs and their approximate distance [5]

\begin{tabular}{ccc}
\hline \hline Origin & Destination & $\begin{array}{c}\text { Distance } \\
\text { (KMs) }\end{array}$ \\
\hline Karachi & Rawalpindi & 1,540 \\
Karachi & Lahore & 1,260 \\
Karachi & Khyber Pass (Afghanistan & 1,756 \\
& Border) & \\
Karachi & Khunjrab Pass (China Border) & 2,400 \\
Karachi & Peshawar & 1,700 \\
Gwadar & Rawalpindi & 2,051 \\
Gwadar & Lahore & 1,771 \\
Gwadar & Karachi & 400 \\
Gwadar & Khunjrab Pass (China Border) & 2,900 \\
Gwadar & Peshawar & 2,211 \\
\hline \hline
\end{tabular}

A report published by The International Trade Centre in 2012, reported that on average inefficiencies in Pakistan freight industry are costing 150 billion PKR annually to the national economy. In the Logistics Performance Index (LPI), Pakistan is ranked at 110th position out of the 150 countries around the globe. This ranking is one of the lowest in terms of performance as compared to other emerging economies in Asia [4]. Currently, a great amount of the total freight transport share (96\%) is transported by the trucking sector which is mainly operated by specific ethnic groups mostly consisting of less than five vehicles, totaling $79 \%$ of the total freight fleet. Most of these small scaled freight operators (1-5 vehicles) are non-registered, non-tax paying, and nonregulated [5].

In this research study, we aimed to address the following driving questions; what are the essential Key Performance Indicators (KPIs) for sustainable freight transport in the emerging nations, how sustainable freight transport may be evolved in Pakistan and what are the core factors which hinder the efficient performance of the freight industry. Also, categorization and projection of the factors in specific scenario-based impediments is done for the improvement in efficient and sustainable freight operations in the country.

The remaining research study is divided into the following sections. Section 2 discusses the pertinent studies from the existing literature about sustainable freight transport and the current condition of freight industry in Pakistan. In section 3, KPIs are discussed which might result in economic growth, increased market connectivity, access to the global supply chain systems, and societal progress and inclusiveness. 
The 8th International Conference on Transportation \& Logistics (T-LOG 2020)

Surabaya September 6th-7th 2020, Universitas Internasional Semen Indonesia (UISI), Gresik, Indonesia

Table 2.

Identified KPIs of each scenario dimension with description

\begin{tabular}{|c|c|c|}
\hline $\begin{array}{l}\text { Research } \\
\text { Dimension }\end{array}$ & KPI & Description \\
\hline \multirow[t]{10}{*}{$\begin{array}{l}\text { Strategic } \\
\text { Determinants }\end{array}$} & Terminal throughputs & $\begin{array}{l}\text { Measures taken to improve the efficiency of the cargo terminal apart from physical capacity such } \\
\text { as; managing domestic and international demand of cargo, contractual arrangements with carriers, } \\
\text { and competition with other freight terminals etc., }\end{array}$ \\
\hline & $\begin{array}{l}\text { Cargo terminals } \\
\text { capacity }\end{array}$ & The use of effective tools to enhance the physical capacity of the cargo terminals. \\
\hline & Government support & Government active role in logistics support and policy making. \\
\hline & Improvement culture & Trends in adopting new technological eco-innovation practices. \\
\hline & $\begin{array}{l}\text { Research and } \\
\text { development initiatives }\end{array}$ & Availability of resources for research and development initiatives. \\
\hline & $\begin{array}{l}\text { Fierce competition } \\
\text { pressure }\end{array}$ & Constant pressure from emerging operators to break the monopoly of existing service providers. \\
\hline & Transshipment share & Fair share of multi-modal shipments over total capacity of the freight terminal. \\
\hline & Labor regulations & $\begin{array}{l}\text { Putting policies in place to reduce the vulnerability of less skilled labor facing dimmer wages and } \\
\text { job perspectives. }\end{array}$ \\
\hline & Terminal operator type & Provision of facilities at terminals designed to handle specific freight types. \\
\hline & Labor costs & Policies for competitive compensation to workers in freight industry to keep them productive and \\
\hline \multirow[t]{9}{*}{$\begin{array}{l}\text { Information } \\
\text { Systems }\end{array}$} & Technology integration & $\begin{array}{l}\text { Integration of latest technologies for multi-modal transit networks to successfully execute freight } \\
\text { operations domestically and internationally. }\end{array}$ \\
\hline & Robust database & $\begin{array}{l}\text { Sustainable design of the system for handling data, security against data crashes, maintaining data } \\
\text { for system availability. }\end{array}$ \\
\hline & $\begin{array}{l}\text { Global sharing and } \\
\text { database protocols }\end{array}$ & Adopting protocols for data sharing meeting standards from high-income or developed countries. \\
\hline & $\begin{array}{l}\text { Location identification } \\
\text { systems }\end{array}$ & $\begin{array}{l}\text { Mandatory inclusion of location identification systems in the vehicles for immediate response in } \\
\text { case of any emergency need. }\end{array}$ \\
\hline & Information acquisition & Making acquisition of data easy, free and accessible to all for research and development purposes. \\
\hline & Information processing & Design of specialized units for the processing of freight related data. \\
\hline & $\begin{array}{l}\text { Information } \\
\text { distribution }\end{array}$ & Any of the information pertinent to freight transport making available to all stakeholders. \\
\hline & Information usage & $\begin{array}{l}\text { Managing internal processes and sharing information with suppliers, customers, and research } \\
\text { community for better operations. }\end{array}$ \\
\hline & $\begin{array}{l}\text { Safety information and } \\
\text { warning } \\
\text { announcements }\end{array}$ & $\begin{array}{l}\text { Technological monitoring of any unplanned incidents beforehand and identification of corrective } \\
\text { actions. }\end{array}$ \\
\hline \multirow{8}{*}{$\begin{array}{l}\text { Infrastructure } \\
\text { Management } \\
\text { Systems }\end{array}$} & Routing & $\begin{array}{l}\text { Routing decisions based on minimum time, cost, number of tolls and emission considering layout } \\
\text { of slopes and consumption. }\end{array}$ \\
\hline & $\begin{array}{l}\text { Traffic management } \\
\text { and congestion } \\
\text { avoidance }\end{array}$ & $\begin{array}{l}\text { Advance traveler information system integration for well-informed decisions to avoid traffic } \\
\text { congestions. }\end{array}$ \\
\hline & $\begin{array}{l}\text { Parking space } \\
\text { management }\end{array}$ & $\begin{array}{l}\text { Parking demand control strategies to assess parking needs for freight and commercial related } \\
\text { services in mitigating these needs. }\end{array}$ \\
\hline & $\begin{array}{l}\text { Speed management } \\
\text { strategies }\end{array}$ & Framework for the safety and mobility of all road-users in the context of specific road conditions. \\
\hline & $\begin{array}{l}\text { Traffic incident } \\
\text { management }\end{array}$ & $\begin{array}{l}\text { Putting planned and coordinated program to assess, detect, respond to, and remove all traffic } \\
\text { incidents as soon as possible to restore the normality of traffic operations. }\end{array}$ \\
\hline & Asset management & $\begin{array}{l}\text { The application of asset management principles to optimize performance and cost-effectiveness } \\
\text { basing decisions on information and goal-oriented outcomes. }\end{array}$ \\
\hline & Agency coordination & $\begin{array}{l}\text { Better coordination between different stakeholders to improve multi-modal environment friendly } \\
\text { solutions achieved through transnational cooperation. }\end{array}$ \\
\hline & $\begin{array}{l}\text { En-route pavement } \\
\text { condition information }\end{array}$ & $\begin{array}{l}\text { Real-time information pertinent to en-route pavement conditions which might affect the overall } \\
\text { movement of the freight in the region. }\end{array}$ \\
\hline \multirow[t]{5}{*}{ City Logistics } & $\begin{array}{l}\text { Infrastructure and } \\
\text { equipment safety }\end{array}$ & $\begin{array}{l}\text { Minimum likelihood of accidents involving human lives and infrastructure per percentage } \\
\text { operations. }\end{array}$ \\
\hline & Intermodal integration & Correct percentage of intermodal allocation based on demand responsiveness. \\
\hline & $\begin{array}{l}\text { Accessibility to freight } \\
\text { terminals }\end{array}$ & Ensuring that all logistics companies have fair and equal access to the freight terminals. \\
\hline & Urban space planning & Improving livability by reducing freight vehicle conflicts with other users. \\
\hline & Institutional complexity & $\begin{array}{l}\text { Keeping interchange procedures easy and fair avoiding unnecessary institutional complexity } \\
\text { levels. }\end{array}$ \\
\hline
\end{tabular}

Section 4 describes the creation mechanism of the scenariobased impediments in freight transport. Section 5 highlights the categorization and projection of main factors hindering the sustainable performance of the freight transport in the country and their negative effects are highlighted on impact areas. Finally, some of the discussions are made on the highlighted factors and impediments, some recommendations are also proposed for the improvement of the sustainable freight operations in the country.

\section{LITERATURE REVIEW}

In recent days, the boost in the world emerging economies is partially because of the improvements and innovations in the freight transport sector. Freight transport has been a determining factor for the choice of the industries' locations and can be linked with the well-being of the humans [2]. In other words, freight transport is one of the inevitable modes which fill the gaps between manufacturers, distributors, suppliers, retailers, and end users in the supply chain management systems. 
The 8th International Conference on Transportation \& Logistics (T-LOG 2020)

Surabaya September 6th-7th 2020, Universitas Internasional Semen Indonesia (UISI), Gresik, Indonesia

Table 3.

Identified key indicators with their characteristics

\begin{tabular}{|c|c|c|}
\hline $\begin{array}{l}\text { Sr. } \\
\text { No. }\end{array}$ & Key indicator & Characteristics \\
\hline 1 & Innovation acceptance & $\begin{array}{l}\text { Acceptance of new technological } \\
\text { models [44] }\end{array}$ \\
\hline 2 & Information sharing & $\begin{array}{l}\text { Relational norms of information } \\
\text { sharing in marketing [44] }\end{array}$ \\
\hline 3 & Industrialization & $\begin{array}{l}\text { Gross domestic product and economic } \\
\text { condition of the country [45] }\end{array}$ \\
\hline 4 & Cargo segregation & $\begin{array}{l}\text { Freight volume division data and } \\
\text { cargo handling at terminals [46] }\end{array}$ \\
\hline 5 & $\begin{array}{l}\text { Research and } \\
\text { development }\end{array}$ & $\begin{array}{l}\text { Trends and practices of research and } \\
\text { development output [47] }\end{array}$ \\
\hline 6 & Political framework & Political stability index data [49-49] \\
\hline 7 & $\begin{array}{l}\text { Logistics } \\
\text { competitiveness }\end{array}$ & $\begin{array}{l}\text { Global logistics performance index } \\
\text { data [50] }\end{array}$ \\
\hline 8 & Security concerns & $\begin{array}{l}\text { Infrastructure investments safety and } \\
\text { cybercrime data [51] }\end{array}$ \\
\hline 9 & E-commerce & Retails net sales in Pakistan [45] \\
\hline 10 & $\begin{array}{l}\text { Compensation } \\
\text { mechanism }\end{array}$ & $\begin{array}{l}\text { Tracking and tracing mechanism of } \\
\text { shipments and compensation surety } \\
\text { [52] }\end{array}$ \\
\hline 11 & $\begin{array}{l}\text { Government } \\
\text { seriousness }\end{array}$ & $\begin{array}{l}\text { Government investment policies and } \\
\text { trends [53] }\end{array}$ \\
\hline 12 & $\begin{array}{l}\text { Technological } \\
\text { advances }\end{array}$ & $\begin{array}{l}\text { Annual patent registration data of } \\
\text { Pakistan [54] }\end{array}$ \\
\hline 13 & $\begin{array}{l}\text { International } \\
\text { shipments }\end{array}$ & International shipments index score \\
\hline 14 & Infrastructure index & Infrastructure index data [55] \\
\hline 15 & Urban space planning & $\begin{array}{l}\text { Urban development trends of } \\
\text { megacities [55] }\end{array}$ \\
\hline 16 & Timeliness & Delivery time score data [55] \\
\hline
\end{tabular}

In the physical distribution systems, it ensures the transport of goods and materials from one location to the other. With all these positive gains, some negative impacts are also arising from the development and complexities of the freight transport system [6]. There is an urgent need for the careful planning and mitigation of the challenges undermining the efficient and sustainable operations in the freight industry.

One of the very common practice to plan and mitigate the negative externalities pertinent to freight transport include reduction in operational costs and improving the profitability margin [1]. A lot of attention has been given to the reduction in the internal costs such as fuel costs, driver's remunerations, and maintenance charges. This approach is quite common and one of the conventional techniques that is widely adopted in the freight industry [7]-[9]. In recent years, the increased concerns of environmental sustainability have pulled together the researchers, government bodies and industry stakeholder in investigating the new and innovative approaches for optimizing freight operations. For the reduction of operating costs and environmental concerns, the introduction of multimodal, intermodal, and co-modal freight transit networks was thought to be one of the strategies adopted [10]. These measures can provide partial relief from the negative externalities caused by the freight transport and still much more is needed to be accomplished.

Sustainable development as defined by Keeble et al. [11] is, "development that meets the needs of the present without compromising the ability of future generations to meet theirs". This concept of sustainability if incorporated in freight transport systems, it can be implied that sustainable freight transport incorporates the strategic, transparent integration of an organization to achieve its economic, accessibility, environmental and social goals by systematically coordinating between intra- and interorganizational business for the improvement and

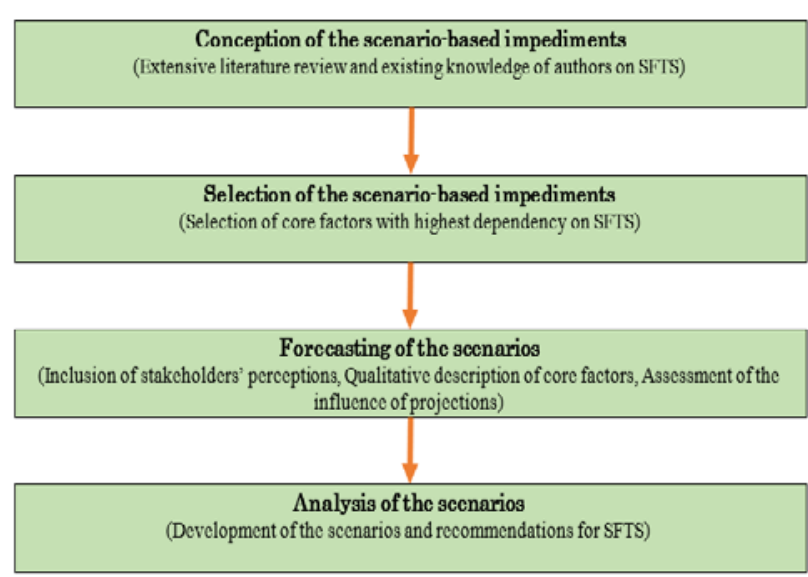

Figure 1. Conception of Scenarios-based impediments for sustainable freight transport.

enhancement of long-term sustainable transit objectives [2]. The sustainability in the freight industry can be said to control the economic, social, demographic, strategic and environmental megatrends. It must be based on innovative, new, safe, high-quality, and easily accessible principles. In other words, sustainable freight transport must in-calculate economically viable, ecologically safe, environmentally harmless dimensions and should positively contribute to the regional, national, and international sustainable development goals [12].

Sustainable freight transport represents an important and significant challenge in modern transit systems which have direct implications to the technical, operational, strategic, and political perspectives in the designing and implementations of the interventions for improved efficiency and performance of the system [13]. Because of the uncertainty of the challenges, it is difficult to assess and quantify the impacts which are of non-trivial importance in freight operations.

Many of the researchers attempted to identify different perceptions of sustainability in freight transport. Kijewska and Jedliński [14] tried to conceptualize the scheme of durability policies for sustainable freight operations. They inferred that over the time many of the policies have been abandoned right after their introduction and proposed that the inclusive approach to include the concerns of all the relevant stakeholder's is a key to success. Vierth et al. [15] performed the ex-post analysis on the impacts of heavier and longer vehicles in Sweden and reported that this policy does not imply any of the discernable effect on modal split.

For driving the concept of sustainability in freight transport requires the inclusion of the technical innovations. The inclusion of technological innovations has the potential to simultaneously improve the economic productivity, improve connectivity, and reduce the negative externalities. However, these substantial initiatives might be hampered by factors pertinent to financial conditions, acceptability perspectives, and managerial decision making. An in-depth analysis of these challenges is imperative to overcome them and proactively engage stakeholders to achieve sustainability [5]. However, to accurately identify country-specific challenges facing freight industry for technological innovations remains a main concern for many organization's managements.

Specially the identification of the factors in freight transport which might boost the economic growth, improve market connectivity, ease the access to the global supply chain 
The 8th International Conference on Transportation \& Logistics (T-LOG 2020)

Surabaya September 6th-7th 2020, Universitas Internasional Semen Indonesia (UISI), Gresik, Indonesia

Table 4.

Negative projections of identified indicators on impact areas

\begin{tabular}{ll}
\hline \hline Impact Areas & Negative Projections \\
\hline \multirow{3}{*}{ Public } & Disinclination of information sharing among stakeholders \\
& Social system stability \\
& Lower reliance on E-commerce \\
& Reluctance in innovative technology acceptance \\
Technological advancements & Growing cybercrime concerns and incidents \\
& Less focus on technical resource management \\
& Poor economic condition and prosperity perspectives \\
Economic growth & Reliability and surety of products quality and services \\
& Barriers to compete with international market \\
& Non-regulated and non-registered fleet in the country \\
& Poor investment initiatives for the revival of rail transport \\
Infrastructure building & Absence of technological oriented trainings of stakeholders \\
& Poor asset management system for efficient operations \\
& Political \& religious upheaval and demonstrations in the country \\
Stakeholders & Forcefully detaining logistics infrastructure as barrier against demonstrations to block protests \\
& Lack of experts' opinion in policy making and investment schemes \\
\hline \hline
\end{tabular}

systems and social development are still lacking in the literature. To the best of the author's knowledge, there has not been conducted any study to highlight these factors which undermine the performance of freight transport in Pakistan. This research study defines the main factors which are deemed important to assess the performance of the freight transport systems in terms of its sustainability perspective. The KPIs are identified to boost the economic growth, market connectivity, access to the global supply chain systems and societal inclusive development. This research study is sought to address the solutions for the following challenges of:

a. Identifying factors to boost economic development

b. Mapping indicators for improved market connectivity

c. Role of strategic planning and stakeholders' feedback for sustainable development of freight operations

d. Recognizing indices to promote cross border supply chain systems

e. Classification and categorization of the identified factors and projecting their negative effects on impact areas

f. Conception of the scenario-based impediments for understanding the principles of sustainability for policy makers, scholars in academia, and professionals for the development of sustainable freight transit operations.

It is worth mentioning that Pakistan's freight transport system can gain exponential progress in terms of sustainability because of the presence of the landlocked countries in the west and big markets of India and China on its sides. However, there is a need to seek the solutions of the above-mentioned challenges. The following section will highlight the present condition of the freight transport in the country.

\section{A. Freight Transport in Pakistan}

Until 1970s, Pakistan rail was one of the main modes of freight transport which shared a great amount (73\%) of the total freight in the country. However, in the recent decades, the inclinations of the government shifted towards road transport and the fleet shared by rail transport dropped to a minimal of $4 \%$. In the previous decade, from 2005-2010, the budgetary allocation to rail transport was 45.5 billion PKR. However, the investments in the national highways stood at 155 billion PKR [16]. This accounts for almost $29.35 \%$ of the budget allocated to the road infrastructures. Because of this deteriorated condition, Pakistan Railway takes around 21 to 28 days for delivering freight for a distance over 1,800 KMs, which is around 4-7 times more than the time required in the US and China [4].

The main freight hubs and their distances are shown in Table 1. The average distance between any of the two business hubs is more than $1000 \mathrm{KMs}$, which implies that rail transport is the most economical and sustainable freight transit option over longer distances as compared to any other freight transport modes.

The LPI of Pakistan is 2.5, which is less than many of the emerging economies such as Vietnam, Thailand, India, Brazil, and Argentina. The average cost of transportation is even above $30 \%$ of the delivered product [17]. In Pakistan, transport sector accounts for $5.39 \%$ of the employment and $10 \%$ of the Gross Domestic Product (GDP). The freight transport sector consumes around 35\% of the annual energy and its share to the Gross Capital Formation (GCF) stand at $11.5 \%$ [4].

As the main freight fleet is trucking sector (96\%) and only minimal (4\%) is constituted by rail transport. However, unfortunately, the trucking sector is very un-regulated and unorganized [5]. Trucking sector is very informal and the actual statistics about the operations are difficult to calculate. Different studies predict different proportions and figures about the operational trucks. For example, a study in 2011 indicated that there were 223,152 registered trucks in the freight fleet. However, the estimates of the Government of Pakistan revealed that there were only 93\% of these trucks are operational, rest $7 \%$ are not-operational due to their deteriorated and poor working conditions. Another study claimed that there were 293,000 commercial cargo trucks in the country which are part of the fleet [4]. This discrepancy and inconsistency in the actual numbers depict the fact that the trucking sector is very informal and very little attention has been given to the freight sector by government with almost non-existent research policies and trends in the country. In the recent decades, Pakistan has been experiencing poor markets due to its inefficient and un-sustainable freight operations which is costing around $30-40 \%$ in the form of agricultural waste due to poor, outdated, and inefficiently equipped freight transport sector [18].

The Central Asian Republic states are rich in terms of main energy supplies in the world. The anticipated energy consumption markets for those states are India and China. The geostrategic positioning of the country makes it an essential corridor if energy must be passed to these two giant 


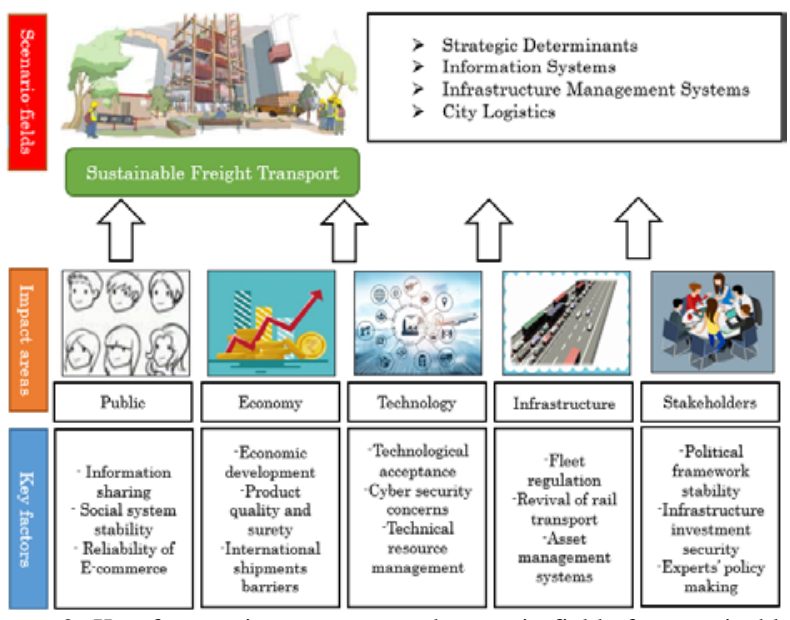

Figure 2. Key factors, impact areas and scenario-fields for sustainable freight transport.

economies. Further, the reach of China, which emerged as a major exporter, to the middle east is not possible economically without the support of the country. This agrees on the argument that Pakistan is a main freight corridor by virtue of its strategic location. With the help of improved freight transit operations, both at ports and through the country, Pakistan can gain exponentially by providing key access to the Indian Ocean and Persian Gulf.

Despite of the enormous capacity of revenue collection, less than $1 \%$ of the allocated budget is spent on the research and institutional capacity building of freight transport sector in the country [19]. This is the major reason that country still lacks technical capacity and has to rely upon the foreign assistance for the formulation of any policies and technical programs pertinent to freight transport.

\section{KPIS FOR SUSTAINABLE FREIGHT TRANSPORT}

Sustainable freight transport has gained much attention in the recent decades. The current technical and scientific discussion on sustainable freight transportation is mainly defined based on performance evaluation monitoring which mainly focuses on a set of defined parameters, known as Key Performance Indicators (KPIs) [20]. Monitoring and assessment of any business usually requires the establishment of different measurement and evaluation approaches, where system of KPIs can be an appropriate tool for performance assessment, operational control and organizational decision making for improved efficiency and sustainability of the systems [21].

Mostly, sustainability in transport and freight systems is defined for a variety of economic, social, environmental, accessibility, and mobility system performances. The economic domain revolves around the affordability for all, efficient movement of goods and people at cheaper fares, selfsufficiency of local transit systems, and economic sustenance of the system against societal vulnerabilities [21]-[24]. The social domain includes, consistency with human health and safety, input from different levels of government and society, promotion of social interactions and social equity, and access to the basic needs of all individuals [25]. The environmental domain stresses on the reduction of emissions, minimize consumptions, maximize land efficiency, minimize impacts on ecological systems, and limiting transport system related waste and noise pollution [26]-[28]. The accessibility domain of sustainability involve reduction in average travel time and travel costs, increased satisfaction of the population nonwork-related commuting trips, and it affects both on social and economic domains [22], [29]. However, mobility system performance domain includes, safety and security, intermodal connectivity, system resilience, and active mobility options. There are numerous research studies on each domain and they usually focus on the operational side of freight transport sustainability [21], [30], [31]. However, this research study highlights KPIs relevant to planning and infrastructural domains of sustainability.

Most of the KPIs are generally relevant to the operational side of the freight transport, neglecting the Strategic Determinants (SD), Information Systems (IS), Infrastructure Management Systems (IMS), and City Logistics (CL). The current research study is aimed at focusing on different sets of KPIs which will emphasize the sustainable perspectives of the freight transport systems.

Strategic Determinants (SD) refer to the strategic planning factors that maps the progress and evaluation of an enterprise in the public and private sector [32]. A turbulent strategic planning is an effective tool to assess the flexibility of an organization to adopt to rapidly changing, uncertain and challenging environments [33]. An efficient freight transport system is considered as a life wire for any nation's economic boost, global connectivity, and societal development (quality of life). The strategic determinants include the decisions about which system to use, based on factors of land cost, available technology, labor productivity and experiences of the economies [34].

According to [35], Information Systems (IS) include the data which is pertinent to the economic phenomena and can be used for the planning processes in decision making. In these modern times, the actual processing of the information is deemed increasingly important for the management and operation of freight transport. The role of the information systems not only include operations within the company but entwinning all departments, subsidiaries, divisions and affiliates and employees, regarded as the nervous system of the freight industry [36]. Limited access to the information sharing does not only restrict the freight operations in the market, but without proper information sharing, freight industry does not arise and cannot sustain. Effective information systems allow freight industry to gather the knowledge of ongoing trends and needs in the society and market, helping how to plan processes and actions. Finally, this "Nervous System" can allow the freight operators to reach the recipients of their products or services, allowing their businesses to grow, arise, and flourish as per recent market demands [37].

Infrastructure Management Systems (IMS) play a vital role in regional and global freight connectivity. The scope of IMS is not only restricted to the highway traffic, it includes arterial and freeway management systems, transit management systems, incidents management systems, and multi-modal integration systems [38]. Many of the developed nations have been using these systems for freight operations controlling. For example, California Freeway Management System processes the real-time data for controlling and monitoring freeway traffic [39]. Transit management systems incorporate the real-time position, satisfaction security and safety of the travelers and goods. It deals with improved mobility, service reliability, and response to the disrupted freight operations. 
Transit management systems allow customers to get real-time information about dispatched product or services integrated with automatic vehicle location systems. Incident management systems are quite significant dimension in sustainable freight operations [38]. According to an estimation, around 1.2 million people die on roads each year apart from costing around 30 billion USD. The forecasts predict that road fatalities due to unexpected events will be fifth foremost reason of death along with financial losses in 2030 [40]. Incident management systems encompasses many sub-systems such as roadway incident management systems, incident detection systems, cyber physical systems, and decision support systems for real-time data collection and management in case of accidents [38]. The detailed discussion about sub-systems will go beyond the scope of this research study. Multi-modal integration systems assist the amalgamation of different transit modes on both ends of manufacturing processes and end user's delivery systems using technology assimilating real-time data and information. It may include timely dispatching the right-sized vehicle keeping a good balance between supply-demand mechanisms. This system is quite effective for freight container transshipments at container centers for operations cost reduction [41].

City logistics is an important domain in urban freight operations or logistics. It encompasses the interdependencies between logistics systems, public welfare, and public administration of logistics operations [42]. The idea of city logistics emerged recently with major goals to assess the performance of urban freight and devise policies or methods to optimize the overall performance pertinent to urban freight transport. The very basic concept of city logistics or this school of thought emerged from Japan, The Netherlands, and Australia but now it has its adherents throughout the world [8]. It broadly includes the methods or techniques of traffic simulations and demand modeling for reducing negative menaces of economic, social, efficiency and environmental concerns. According to Eiichi et al., [43], the city logistics can be defined as; "the process for totally optimizing the logistics and transport activities by private companies in urban areas while considering the traffic environment, traffic congestion and energy consumption within the framework of a market economy."

Based on the extensive literature review and the best knowledge of the authors, some of the KPIs are identified pertinent to each domain (SD, IS, IMS, and CL) of freight transport. Establishment of the proper policy measures relevant to each indicator are expected to produce positive externalities or outcomes for efficient and sustainable freight operations, especially in the developing nations. These KPIs are conveniently divided into each dimension or category as shown in Table 2.

\section{SCENARIO ANALYSIS ON SUSTAINABLE FREIGHT TRANSPORT}

The creation of the scenarios is based on the extensive literature review and the knowledge of the authors of sustainable freight transport systems. The role of the key stakeholders and core factors, which are used as descriptive features are anticipated and incorporated as negative projections in each scenario-based impediment for sustainable freight transport systems. The projections are utilized in the formation of different scenarios which strictly adhere to the methodological considerations (extensive literature review and existing knowledge) and these projections are supported by the relevant literature studies. The chronological sequence of the adopted methodology which basis the conception and creation of these scenariobased impediments is manifested in the Figure 1.

The creation of the scenarios is based on the highest dependency of the negative projections of the defined key factors pertinent to sustainable freight transportation. The directly relevant impact areas such as; economic growth, public, technological advances, infrastructure building, and inputs from stake-holders are defined with these definite factors. However, the interdependency analysis of the negative projects of the defined factors was assessed and evaluated for each specific scenario-based impediment. Based on the categorization of the factors, the following final scenario-based impediments are established; Strategic Determinants (SD), Information Systems (IS), Infrastructure Management Systems (IMS) and City Logistics (CL). The detailed key indicators and their impact areas are discussed in the next section (section 5).

\section{KEY INDICATORS AND IMPACT AREAS}

There are different perspectives and perceptions about indicators. Indicators can reflect various levels of decision making, physical impacts, economic impacts, environmental impacts, and responses. However, many of the indicators can be best evaluated based on their characteristics and relative indicator systems. Each of the key factor shown in Table 3 is related with its most important characteristics which hinders the sustainability in the freight operations. These carefully evaluated key factors are ranging from technological innovations, social interactions, logistics market competitiveness and socio-economic diversity. The interdependency analysis of key factors with their characteristics is shown in Table 3.

It is very necessary and imperative to highlight the negative projections of each identified key factor on subsequent impact areas, which are deemed important for sustainable development of freight transportation. Also, it is important to mention that these impact areas are selected based on the direct relevance of indicators' projection. The negative projection of the identified key factors and their impact areas are highlighted in Table 4. The details of the identified key factor with their impact areas are shown in Figure 2.

\section{DISCUSSIONS AND CONCLUSIONS}

This study was aimed at highlighting the key performance indicators which can be used as guidelines for economic growth, market connectivity, and access to the global supply chain systems of sustainable freight transport systems in the emerging economies. As a case study, the identification of the core factors which project negative effects on the sustainable freight transit operations in Pakistan are evaluated and discussed. Furthermore, each of the key factor was categorized and linked with specific scenario-based impediments of Strategic Determinants (SD), Information Systems (IS), Infrastructure Management Systems (IMS) and City Logistics (CL). The role of each of the defined key factor was much important and crucial for its quantification on the 
impact areas of these specific impediments. It is imperative to mention that the role of the government is very much crucial for the up gradation of the freight operations and they must undergo an extra mile to achieve the far-reaching milestones in the freight industry. The involvement of the technical personnel from academia and industry, along with the feedback from the stakeholder's is much inevitable for the formulation and design of efficient and sustainable freight transit policies.

There is an urgent need of devising Standard Operating Procedures (SOPs) for the quality control of vehicles and drivers on road. The most important of all, the government must seek the expertise of the professional for the revival and upgradation of the rail transport sector. As there is no doubt, rail transport is one of the safest and most economical freight transit mode for hauling over long distances [56]. The regulation, organization, registration, and taxation of the trivial small-scaled trucking sectors must be brought into the national exchequer for check and balance and effective policy design. The modernization of the trucking sector is a prerequisite if the country is looking upon as a regional hub for expanded international trade in Indian and Persian Ocean. In return, it can boost the efficient and sustainable freight operations in the country. Infrastructure investments must comply with the technical feasibilities formulated and presented by the professional bodies instead of political inclinations. External consultants or regulatory body must be put in place to ensure the strict compliance of the designed guidelines and SOPs in the freight companies and heavy penalties must be sanctioned on those who show little or nocompliance with policy guidelines.

Along with the integration of the freight operations of Pakistan with the international freight operations, the geostrategic position of the country dictates that it can emerge as a regional hub for the connectivity of Central Asian States, India, and China. However, the extended facilities at the ports, ease in cross-border regulations, and better connectivity of resourceful rail network in the country will serve as key to step-forward sustainable freight transport in the region.

However, it is important to mention that the validity of the negative projections of the defined indicators must be treated very carefully. There is a possibility that different authors may not possess the same projections background as of authors and propose different interdependency analysis for the conception and formulation of specific scenario-based impediments. In addition, the scope and consolidation of the idea for this specific study is restricted to the identification of the factors which are in association and relevance to the geo-political situations in Pakistan specifically and emerging economies generally, which are central to the sustainable freight transit operations.

In the future studies, these projections and scenarios-based impediments would be better validated by expert surveys (i.e., questionnaire surveys) or a Delphi-analysis would be conducted. Inclusion of more factors and their projections might be evaluated for the assessment and evaluation of sustainable freight transport in the country to derive their implications on economic growth and policy formulation. An extended and detailed study might be conducted to propose effective and operative technical solutions keeping in view of the contextual scenarios proposed in this study for sustainable freight operations in Pakistan.

\section{REFERENCES}

[1] N. Arvidsson, “Operational freight transport efficiency - a critical perspective,” Fek, vol. Licentiate, no. November, p. 124, 2011.

[2] A. Kumar and R. Anbanandam, "Assessment of environmental and social sustainability performance of the freight transportation industry: An index-based approach,” Transp. Policy, 2020, doi: 10.1016/j.tranpol.2020.

[3] B. Kin, S. Verlinde, and C. Macharis, "Sustainable urban freigh transport in megacities in emerging markets," Sustain. Cities Soc., vol. 32, pp. 31-41, 2017, doi: 10.1016/j.scs.2017.03.011.

[4] The international Trade Centre, "Road Freight Transport Sector \& Emerging Competitive Dynamics,” p. 39, 2012.

[5] N. Ali and A. Rahim, "Scenario-Based Impediments for Intelligent Freight Transportation in Pakistan,” 2018 15th Int. Conf. Smart Cities Improv. Qual. Life Using ICT IoT, HONET-ICT 2018, no. March 2019, pp. 97-101, 2018, doi: 10.1109/HONET.2018.8551329.

[6] A. De Marco, A. C. Cagliano, G. Mangano, and F. Perfetti, "Factor influencing logistics service providers efficiency' in Urban distribution systems,” Transp. Res. Procedia, vol. 3, no. July, pp. 499507, 2014, doi: 10.1016/j.trpro.2014.10.031.

[7] T. Baudel, L. Dablanc, P. Alguiar-Melgarejo, and J. Ashton, "Optimizing Urban Freight Deliveries: From Designing and Testing a Prototype System to Addressing Real Life Challenges,” Transp. Res. Procedia, vol. 12, no. June 2015, pp. 170-180, 2016, doi: 10.1016/j.trpro.2016.02.056.

[8] I. Cardenas, Y. Borbon-Galvez, T. Verlinden, E. Van de Voorde, T. Vanelslander, and W. Dewulf, "City logistics, urban goods distribution and last mile delivery and collection,” Compet. Regul. Netw. Ind., vol. 18, no. 1-2, pp. 22-43, 2017, doi: 10.1177/1783591717736505.

[9] A. Comi, M. M. Schiraldi, and B. Buttarazzi, "Smart urban freight transport: tools for planning and optimising delivery operations," Simul. Model. Pract. Theory, vol. 88, no. February, pp. 48-61, 2018, doi: 10.1016/j.simpat.2018.08.006.

[10] J. Woxenius, "Directness as a key performance indicator for freight transport chains,” Res. Transp. Econ., vol. 36, no. 1, pp. 63-72, 2012, doi: 10.1016/j.retrec.2012.03.007.

[11] B. R. Keeble, “The Brundtland Report: 'Our Common Future,'” Med. War, vol. 4, no. 1, pp. 17-25, 1988, doi: $10.1080 / 07488008808408783$.

[12] UNCTAD, "UNCTAD Framework for Sustainable Freight Transport," 2017, [Online]. Available: https://sft-framework.org/.

[13] A. Mckinnon, "Performance Measurement in Freight Transport: Its contribution to the design, implementation and monitoring of public policy,” Int. Transp. Forum - OECD, no. February, 2015.

[14] K. Kijewska and M. Jedliński, "The concept of Urban Freight Transport Projects durability and its assessment within the framework of a Freight Quality Partnership,” Sustain., vol. 10, no. 7, 2018, doi: 10.3390/su10072226.

[15] I. Vierth, S. Lindgren, and H. Lindgren, "Vehicle weight, modal split, and emissions-an ex-post analysis for Sweden,” Sustain., vol. 10, no. 6, 2018, doi: 10.3390/su10061731.

[16] M. A. Choudhary, N. Khan, M. Arshad, and A. Abbas, "Analyzing Pakistan' s Freight Transportation Infrastructure Using Porter' s Framework and Forecasting Future Freight Demand Using Time Series Models,” 2nd WSEAS Int. Conf. URBAN Plan. Transp. Anal., 2007, [Online]. Available: http://www.wseas.us/elibrary/conferences/2009/rodos/UPT/UPT08.pdf.

[17] : Pajcci and R. Wing, "Comparative Analysis of Logistics Performance Index (LPI) of Pakistan and Iran: Future Prospects of Trade with Afghanistan," 2016, [Online]. Available: http://www.pajcci.com/Downloads/LPI Ranking Pakistan vs. Iran.pdf.

[18] R. Siddiqui, "Quantifying the impact of development of the transport sector in Pakistan,” Pak. Dev. Rev., vol. 46, no. 4, 2007, doi: 10.30541/v46i4iipp.779-802.

[19] Chintkuntla, “Council for Innovative Research,” J. Adv. Chem., vol. 10, no. 1, pp. 2146-2161, 2015.

[20] T. Litman, "Sustainable Transportation Indicator Data Quality and Availability,” 2010 Transp. Res. Board Annu. Meet., p. 8, 2009.

[21] J. Zheng, N. W. Garrick, C. Atkinson-Palombo, C. McCahill, and W. Marshall, "Guidelines on developing performance metrics for evaluating transportation sustainability,” Res. Transp. Bus. Manag., vol. 7, pp. 4-13, 2013, doi: 10.1016/j.rtbm.2013.02.001.

[22] H. S. Kristle Nathan and B. S. Reddy, "Urban transport sustainability indicators - Application of multi-view black-box (MVBB) framework,” Int. J. Environ. Sustain. Dev., vol. 12, no. 3, pp. 285-312, 2013, doi: 10.1504/IJESD.2013.054955.

[23] Z. Liu, Y. Ren, L. Shen, X. Liao, X. Wei, and J. Wang, “Analysis on the effectiveness of indicators for evaluating urban carrying capacity: 
The 8th International Conference on Transportation \& Logistics (T-LOG 2020)

Surabaya September 6th-7th 2020, Universitas Internasional Semen Indonesia (UISI), Gresik, Indonesia

A popularity-suitability perspective,” J. Clean. Prod., vol. 246, p. 119019, 2020, doi: 10.1016/j.jclepro.2019.119019.

[24] L. K. Mitropoulos and P. D. Prevedouros, "Incorporating sustainability assessment in transportation planning: an urban transportation vehiclebased approach,” Transp. Plan. Technol., vol. 39, no. 5, pp. 439-463, 2016, doi: 10.1080/03081060.2016.1174363.

[25] H. Haghshenas and M. Vaziri, "Urban sustainable transportation indicators for global comparison,” Ecol. Indic., vol. 15, no. 1, pp. 115121, 2012, doi: 10.1016/j.ecolind.2011.09.010.

[26] N. Cohen, P. Robbins, and T. Bauler, "Sustainability Indicators," Green Cities An A-to-Z Guid., vol. 12, no. January, 2012, doi: 10.4135/9781412973816.n127.

[27] A. Dobranskyte-Niskota, A. Perujo, and M. Pregl, Indicators to assess sustainability of transport activities. 2007

[28] T. Litman, "Developing indicators for comprehensive and sustainable transport planning,” Transp. Res. Rec., no. 2017, pp. 10-15, 2007, doi: 10.3141/2017-02.

[29] C. Prandi, S. Mirri, S. Ferretti, and P. Salomoni, "On the need of trustworthy sensing and crowdsourcing for urban accessibility in smart city,” ACM Trans. Internet Technol., vol. 18, no. 1, pp. 1-21, 2017, doi: $10.1145 / 3133327$.

[30] S. Munira and D. S. Santoso, "Examining public perception over outcome indicators of sustainable urban transport in Dhaka city," Case Stud. Transp. Policy, vol. 5, no. 2, pp. 169-178, 2017, doi: 10.1016/j.cstp.2017.03.011

[31] I. P. C. Braga, H. F. B. Dantas, M. R. D. Leal, M. R. De Almeida, and E. M. Dos Santos, "Urban mobility performance indicators: A bibliometric analysis,” Gest. e Prod., vol. 26, no. 3, pp. 1-17, 2019, doi: 10.1590/0104-530X3828-19.

[32] F. Authors, "Strategic determinants : the," J. Manag. Psychol., vol. 13, no. $1 / 2$, pp. 7-21, 1998.

[33] A. Michele and P. Serra, "Strategic determinants of terminal operating system choice: An empirical approach using multinomial analysis,” Transp. Res. Procedia, vol. 3, no. July, pp. 592-601, 2014, doi: 10.1016/j.trpro.2014.10.038.

[34] H. Ghazanfari and S. Zohrevandi, "Role of Strategic Planning in Transportation Management Company,” no. December 2013, 2002.

[35] J. Grabara, M. Kolcun, and S. Kot, "The role of information systems in transport logistics,” Int. J. Educ. Res., vol. 2, no. 2, pp. 1-8, 2014.

[36] R. Farzaneh, T. Ramani, A. Krishnan, and J. Zietsman, "Performance Measures for Sustainable Freight Movement Final Report University Transportation Center for Mobility ${ }^{\mathrm{TM}}$,” no. February, 2012, [Online]. Available: http://utcm.tamu.edu/publications/final_reports/Zietsman_09-3715.pdf.

[37] F. Russo, C. Rindone, and P. Panuccio, "European plans for the smart city: from theories and rules to logistics test case,” Eur. Plan. Stud., vol. 24, no. 9, pp. 1709-1726, 2016, doi: 10.1080/09654313.2016.1182120

[38] D. Das, S. Tom, and J. Honiball, "Futuristic Intelligent Transportation System Architecture for Sustainable Road,” Proc. 35th South. African Transp. Conf. (SATC 2016), no. Satc, pp. 207-224, 2016.

[39] C. Chen, K. Petty, A. Skabardonis, P. Varaiya, and Z. Jia, "Mining
Loop Detector Data,” Transp. Res. Rec., no. 01, pp. 96-102.

[40] J. Sawin, E. Martinot, and D. Appleyard, "Global Status Report.," Renew. Energy World, vol. 13, no. 5, pp. 24-31, 2010, [Online]. Available:

http://ra.ocls.ca/ra/login.aspx?url=http://search.ebscohost.com/login.a spx?direct=true\&db=enr\&AN=56097888\&site=ehost-live.

[41] D. Patier, B. David, R. Chalon, and V. Deslandres, "A New Concept for Urban Logistics Delivery Area Booking,” Procedia - Soc. Behav. Sci., vol. 125, pp. 99-110, 2014, doi: 10.1016/j.sbspro.2014.01.1459.

[42] M. a P. Taylor, "The City Logistics paradigm for urban freight transport,” Infrastructure, vol. 18, pp. 1-19, 2006.

[43] T. Eiichi, T. R. G, Y. Tadashi, and van D. Ron, "Introduction,” in City Logistics, Emerald Group Publishing Limited, 2001, pp. 1-15.

[44] M. Ghazizadeh, J. D. Lee, and L. N. Boyle, "Extending the Technology Acceptance Model to assess automation,” Cogn. Technol. Work, vol. 14, no. 1, pp. 39-49, 2012, doi: 10.1007/s10111-011-01943.

[45] S. Sezer and T. Abasiz, "The Impact of Logistics Industry on Economic Growth: An Application in OECD Countries,” Eurasian J. Soc. Sci., vol. 5, no. 1, pp. 11-23, 2017, doi: 10.15604/ejss.2017.05.01.002.

[46] P. T. W. Lee, O. K. Kwon, and X. Ruan, "Sustainability challenges in maritime transport and logistics industry and its way ahead," Sustain., vol. 11, no. 5, pp. 1-9, 2019, doi: 10.3390/su11051331.

[47] V. Himanen, M. Lee-Gosselin, and A. Perrels, "Impacts of transport on sustainability: Towards an integrated transatlantic evidence base," Transp. Rev., vol. 24, no. 6, pp. 691-705, 2004, doi 10.1080/0144164042000272470.

[48] "Pakistan Political stability - data, chart | TheGlobalEconomy.com." https://www.theglobaleconomy.com/Pakistan/wb_political_stability/ (accessed May 11, 2020).

[49] I. Husain, "Journal of International Affairs Editorial Board Author ( s ): Ishrat Husain THE ROLE OF POLITICS IN PAKISTAN ' S ECONOMY,” vol. 63, no. 1, pp. 1-18, 2016.

[50] I. Harris, Y. Wang, and H. Wang, "ICT in multimodal transport and technological trends: Unleashing potential for the future,” Int. J. Prod. Econ., vol. 159, pp. 88-103, 2015, doi: 10.1016/j.ijpe.2014.09.005.

[51] V. Ahmed, A. Abbas, and S. Ahmed, "Public Infrastructure and Economic Growth in Pakistan: A Dynamic CGE-Microsimulation Analysis,” Econ. Stud. Inequality, Soc. Exclusion Well-Being, pp. 117143, 2013, doi: 10.1007/978-3-319-03137-8_5.

[52] " 3 out of 4 Orders from AliExpress Get Lost in Pakistan: Poll." https://propakistani.pk/2016/05/16/3-out-of-4-orders-from-aliexpressget-lost-in-pakistan-survey/ (accessed May 11, 2020).

[53] MINECOFIN, "Budget Call Circular 2013-14.," 2013.

[54] “IPO Pakistan.” http://www.ipo.gov.pk/ (accessed May 12, 2020).

[55] “Country Score Card: Pakistan 2018 | Logistics Performance Index.” https://lpi.worldbank.org/international/scorecard/line/56/C/PAK/2018 (accessed May 12, 2020).

[56] V. B. G. Campos, R. A. R. Ramos, and D. De Miranda E Silva Correia, "Multi-criteria analysis procedure for sustainable mobility evaluation in urban areas,” J. Adv. Transp., vol. 43, no. 4, pp. 371-390, 2009, doi: 10.1002/atr.5670430403. 